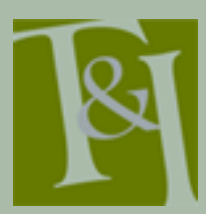

The International Journal for Translation \& Interpreting Research

trans-int.org

\title{
Conceptual construct and empirical validation of a multifaceted instrument for translator satisfaction
}

\author{
Mónica Rodríguez-Castro \\ University of North Carolina at Charlotte \\ Monica.Rodriguez@uncc.edu
}

DOI: $10.12807 /$ ti.107202.2015.a03

\begin{abstract}
The evolution of the language industry over the last two decades has led to drastic changes in the translation process, the translator professional profile and overall organizational dynamics within the industry. Globalization trends such as the advent of Internet-related technologies, outsourcing and the emergence of new organizational structures have modified the modus operandi across the language industry. These trends have affected translator work behaviour, particularly individual levels of satisfaction or dissatisfaction with the workplace, and arguably redefined the profession itself. Despite the significant impact of these trends, translator satisfaction has been overlooked in translation studies. This article presents an attempt to understand satisfaction in the language industry and develop an instrument for specifically measuring task and job satisfaction among translators. Translator satisfaction is assessed through an online survey questionnaire that is designed to gather quantitative and qualitative data. The process of instrument development, piloting, data collection and preliminary empirical validation are also presented in this paper in order to comprehend sources of satisfaction or dissatisfaction among active translation professionals.
\end{abstract}

Keywords: Translation, job index, task index, satisfaction, language industry.

\section{Introduction}

The relatively nascent language industry (LI) has undergone a rapid transformation since the 1990s. This transformation can be observed from the expansion of the industry with annual revenue projections of approximately USD 37.19 billion in 2014 (DePalma, Hegde \& Pielmeier, 2014), and the growth from 2010 to 2015 ranging from 10 to $13.15 \%$ (Kelly \& Stewart, 2010, p. 3). Dunne (2011a) estimates that "the size of the language industry range[s] from EUR 8.5 billion ...to USD 23.3 billion... and as high as USD 30 billion" (p. 183). The rapid growth has not only reshaped the translation profession but has also significantly modified the traditional translation process and organizational dynamics to the point of becoming extensively digital, characterised by the predominance of project-based organizations and the widespread adoption of the subcontracting model (Dunne, 2012, p. 143). Additionally, a significant increase in volume and levels of task complexity has made the industry volatile (Rodríguez-Castro, 2013, p. 38) and dynamic with tight deadlines being widely prevalent.

Globalisation trends and the digital revolution have accelerated such organisational dynamics as outsourcing. Translation buyers have adopted horizontal and flexible organisational structures, and subcontracting such language services as translation, postediting, localisation, etc. to language service providers (LSPs) has become predominant. In fact, approximately $90 \%$ of 
language services are outsourced (DePalma \& Beninato, 2008, p. 1). Translation clients outsource to LSPs, and LSPs in turn subcontract to a network of translation professionals who are distributed among intercultural labour forces working in virtual teams. Outsourcing has not only afforded clients the opportunity to focus on their core competences, but has also been the recourse to find the appropriate expertise for higher levels of complexity.

With the implementation of outsourcing and the expansion of the World Wide Web, the LI has become predominantly digital (Dunne, 2012, p. 144) with source texts that are authored in complex digital formats. In turn, the 'art and craft' of translation has turned into mass-production language processing where standardisation has become imperative (García, 2009, p. 200; Rodríguez-Castro, 2013). The advent of mass production language processing methods has resulted in an increased division of labour and specialisation of a wider variety of skills. Server-based systems, client-server software, new authoring systems, management systems (García, 2009, p. 201) and numerous computer-assistedtranslation applications have played a crucial role in the evolution of the LI. As a result, translation professionals have been challenged to undertake tasks with higher levels of (technical) complexity in translating digital content (García, 2009, p. 200; Kelly, 2014; Ehrensberger-Dow \& Massey, 2014) while wearing multiple hats in order to remain competitive.

The evolution of the industry has challenged the traditional role of translation professionals. Translation professionals in today's work settings are used to offering a wide variety of services and performing a wide range of tasks. Besides the most common tasks like translation and editing, translators perform servicerelated tasks such as quoting, sales and marketing. Thus, the overall complexity of the job has increased in a short span of time, and the same job now requires a wider number of competences with a highly-technical skill set.

Due to the adoption of outsourcing and flexible organisational structures, the major sources of satisfaction and dissatisfaction that affect translation professionals need to be investigated. Translator satisfaction has received limited attention in the existing literature of translation studies (Dam \& Zethsen, 2011), and the development of a theoretical construct has become essential to comprehend the influence of multiple trends significantly affecting the work setting and the workflow. Previous studies have mostly focused on a few components pertaining to translation jobs (Kuznik \& Verd, 2010) and professional satisfaction factors such as occupational status (Dam \& Zethsen, 2009), as well as salary, education, visibility and power or influence (Dam \& Zethsen, 2011). Additionally, the literature from psychology has identified disagreements in the measurement of satisfaction (Frey \& Stutzer, 2002; Skalli, Theodossiou \& Vasileiou, 2008). Hence, these disagreements and the lack of a holistic framework call for research into the sources of satisfaction and dissatisfaction in the LI. The aim of this paper is to fill the gap in the existing literature by developing a comprehensive instrument that assesses translator satisfaction, particularly designed to measure specific sources of task and job satisfaction in the LI.

\section{Construct of Translator Satisfaction}

This section defines the concepts of satisfaction in order to capture the inherent complexity of current work environments in the LI. Even though there is an extensive amount of literature in occupational and organisational psychology that investigates job satisfaction in corporate settings, there is limited research on job satisfaction in translation studies. Additionally, the consequences of the 
outsourcing model have been overlooked because the literature in psychology has mainly focused on in-house corporate environments. Therefore, the direct application of concepts from other disciplines to the LI is challenging. This section introduces the concepts that will be assessed through the instrument presented in the subsequent sections. Some of these concepts are borrowed from existing literature in other fields of study, while others are adopted to suit the study of translator satisfaction.

Some scholars have framed their studies on satisfaction within the realm of industrial organisational psychology, while others have based their studies on behavioural and social sciences. Job satisfaction has been defined in multiple ways, with the sources of satisfaction being diverse and bound to the specific characteristics of work settings. The concept of job satisfaction refers to the positive attitude that an individual derives from the work itself (also known as an intrinsic source of satisfaction) in conjunction with the multidimensional contextual aspects that affect individual work behaviour (commonly referred to as extrinsic sources). As Klein (1989, pp. 63-64) asserts, the concept of satisfaction at work, as studied in the field of organisational behaviour, is replete with "splintered and perplexing theories" of work motivation that create "conceptual clutter" for researchers. Furthermore, the traditional models of (job) satisfaction have only explored a limited number of sources of satisfaction since work environments were generally static. Early models of satisfaction explored a limited number of external sources of satisfaction, thus limiting the construct of satisfaction.

This study classifies concepts from the literature in dealing with individual, group or team (job) satisfaction. Herzberg's two-factor theory (1959) is used as the main theoretical framework for this study since it establishes the crucial dichotomy between intrinsic (individual) and extrinsic (job and team) sources of satisfaction. According to Herzberg (2003), "the opposite of job satisfaction is not job dissatisfaction but, rather, no job satisfaction (p. 56), meaning that job content factors ('motivators') are key contributors of satisfaction if present in the work setting since they are stimuli for growth. The second grouping consists of job context factors that are 'hygiene' or dissatisfaction-avoidance elements, extrinsic to the job (p. 57). Herzberg's construct is adopted in this study: motivators are understood as intrinsic sources of motivation and job context factors are viewed as extrinsic sources of satisfaction. This study also outlines an extensive list of concepts to assess the paradigm of translator satisfaction in order to understand the (a) individual sources of satisfaction included under the category of task satisfaction, and (b) external sources of satisfaction often present at the work setting or visible in virtual teamwork included under job satisfaction. Each category and its constituent concepts are explained below.

\subsection{Task Satisfaction}

Task satisfaction is operationally defined as the positive attitude experienced by a worker during, or upon completion, of a task (Fisher, 1980). Task satisfaction derives from a feeling of success that is intrinsic to the individual and captures key intrinsic motivators like growth, recognition, achievement and the nature of the work itself (Herzberg, 1959). Task satisfaction can be considered as a psychological construct that is associated with individual perceptions of the specific tasks that compose the work associated with a role. For instance, the role of a translator consists of such tasks as translating, proofreading, and so on. The level of task satisfaction varies quite strongly with the "feeling of knowing" (FOK), also referred to as task familiarity. FOK is a metacognitive phenomenon that is known to affect the evaluation of task satisfaction (Koriat, 1993; Metcalfe, 
Schwartz \& Joaquim, 1993), and is intrinsically related to self-efficacy, or understanding of the nature of a task and task complexity.

Self-efficacy is self-assessment of capabilities and the ability to regulate the success or failure associated with tasks that are being performed (Bandura, 1995). The impact of efficacy is related to self-appraisal, stronger goal challenges, higher task commitment (Locke and Latham, 1990), higher levels of analytical thinking, and higher metacognitive regulatory processing. Douthitt and Aiello (2001) argue that self-regulation, participation and control over monitoring may lead to increased task satisfaction. According to Mason and Griffin (2002, p. 299), taskspecific factors (familiarity, opportunity for feedback, etc.) in conjunction with procedural skills enhance task satisfaction. FOK, therefore, grows as task familiarity and awareness grow, often reflecting deeper understanding of the specific nature of tasks. Shreve (2002) discusses the role of metacognitive development in successful task completion among translators, arguing that a translator develops metacognitive knowledge and patterns of useful cues for successful problem solving during the acquisition history. The author emphasises that those patterns "enable the recognition of successful task completion" to a greater extent in experts but also in novices $(2002,162)$. Different levels of metacognition or FOK are intrinsically associated with the "expertise effect" (Shreve, 2009; Shreve \& Angelone, 2010) as well as with multiple levels of selfefficacy during task completion. A detailed illustration of the category of task satisfaction is outlined in Table 1.

Table 1.

\begin{tabular}{|c|c|c|}
\hline Self-efficacy & $\begin{array}{l}\text { task scope } \\
\text { task description }\end{array}$ & \\
\hline Nature of the task & $\begin{array}{l}\text { task complexity } \\
\text { task variety } \\
\text { novelty of the task } \\
\text { task pride } \\
\text { task autonomy } \\
\text { occupational level } \\
\text { individual initiative to learn }\end{array}$ & \\
\hline Self-fulfilment & self-actualisation & $\begin{array}{l}\text { individual growth } \\
\text { opportunities to grow at work } \\
\text { feedback }\end{array}$ \\
\hline Feedback & Feedback & $\begin{array}{l}\text { effective feedback } \\
\text { constant feedback } \\
\text { feedback on translation samples }\end{array}$ \\
\hline
\end{tabular}

Self-efficacy is associated with task scope and task description, crucial concepts that impact task satisfaction. Even though task scope and task descriptions vary from project to project, deliberate practice may lead to positive feelings toward task scope and description. The more projects a translator is involved in, the greater the experience with task scopes and descriptions. Experienced translators generally understand the overall parameters of a task such as the nature of inputs, expectations for outputs, tools that could and should be used, and having a greater tolerance for unclear task descriptions.

The literature on satisfaction recognises the concept of the nature of the task among the major motivators. Herzberg (1959) found that the work itself, 
responsibility and advancement are strong intrinsic motivators, adding that, "frequently cited desiderata were creative or challenging work, varied work, and an opportunity to do a job completely from the beginning to end" (p. 61). In the translation profession, translators may work with either general or specialised texts, requiring a wide range of subject matter expertise to overcome challenges associated with linguistic, textual and extralinguistic difficulties (see PACTE, 2011, for more details). In fact, highly specialised translators are expected to exhibit higher task satisfaction since they enjoy the challenges presented by complexity, and take pleasure in rendering translations related to their field of specialisation.

Translators also need to deal with task complexity in order to undertake tasks. Tasks vary in complexity, ranging from general to specialised translation and may require advanced knowledge and skills in order to deal with terminological complexity and domain specific usage. As a result, aspects such as technical expertise, specialisation and terminological complexity are key contributors to a translator's feeling toward task satisfaction. Furthermore, high-need achievers are known to enjoy challenge, complexity and task variety (Herzberg, 1959), since the nature of the task is considered to be an intrinsic motivator. In order to fully understand the nature of the task, it is important to note that the variety of tasks observed in the LI is very broad, due to the multiplicity of roles (proofreader, terminologist, etc.) that can be assumed in the translation work context. For instance, the task variety associated with a translation professional playing the role of a terminologist is very different from the tasks associated with the role of a project manager. The specialisation and complexity attached to each task in the current LI makes task variety an important aspect of translator satisfaction. Lastly, aspects associated with novelty of the task have not received any attention in the literature of translation studies. Some translators become demotivated from translating all day, assuming several new part-time roles in order to keep up their interest in the translation work (Robinson, 1997). Novelty may become a source of intrinsic satisfaction, with a new task providing an opportunity to acquire new skills.

Theories of self-fulfilment posit that people exhibit a positive job attitude when their individual needs are satisfied (Locke, 1976). Self-fulfilment is intertwined with the need for self-actualisation. The term self-actualisation was coined by Goldstein (1939) and was defined by Maslow as "the desire of selffulfilments, namely, the tendency for [an individual] to become actualised ... as the desire to become ... everything that one is capable of becoming" (p. 382). Herzberg (1959) argued that self-actualisation includes the strongest sources of satisfaction among workers. Generally speaking, translators exhibit a sense of pride in learning from the task, and professional growth is an inner attribute observed in them. They often aim at being 'the best translators' so that they can differentiate themselves from the competition. In this study, growth, opportunities to grow at work and feedback are essential concepts that are associated with selffulfilment as potential sources of task satisfaction (see Table 1).

Growth need strength (GNS) has proven to be a key moderator of several aspects of satisfaction, including individual preferences for the need to grow, how people want to be praised, and feedback seeking behaviour (Fried \& Ferris, 1987, p. 84). Ammons (1956) concluded that feedback generally enhances learning and motivation, and it is generally agreed that feedback leads to better performance (Locke \& Latham, 1990). It is, therefore, considered as one of the best predictors of satisfaction (Lambert \& Durand, 1975). In the LI, freelancers argue that feedback, good or bad, provides a better understanding of requirements for new translations (Durban, 2010, p. 212), yet opportunities for effective feedback are 
limited in the current LI (McKay, 2006) and receiving constant feedback is not a common practice. According to Lee (2006, p. 111), constant feedback can enhance healthier relationships. The literature agrees (Lambert \& Durand, 1975; Jawahar, 2006a, 2006b) that opportunities for receiving feedback are strongly correlated with a high level of satisfaction. However, in the LI, feedback tends to be the exception rather than the rule.

\subsection{Job Satisfaction}

Job satisfaction represents an individual's emotional feeling or impression of the set of tasks performed in any work environment(s) over a lengthy period of time. In this sense, a job is seen as a temporal experience of a routinely associated set of tasks accomplished in a particular work context. In this paper, job satisfaction is an individual affective reaction that reflects how the individual feels about the combination of routine tasks done alone or in a team. It is also possible for an individual to work simultaneously in multiple work environments and play the same role in all of them.

Table 2.

Construct of Job Satisfaction

\begin{tabular}{|c|c|c|}
\hline \multirow[t]{6}{*}{ Individual job-fit } & \multicolumn{2}{|l|}{ nature of the job } \\
\hline & \multicolumn{2}{|l|}{ Workload } \\
\hline & \multicolumn{2}{|l|}{ Remuneration } \\
\hline & \multicolumn{2}{|l|}{ Deadlines } \\
\hline & \multirow{2}{*}{\multicolumn{2}{|c|}{$\begin{array}{l}\text { balance between work/personal life } \\
\text { job turnover }\end{array}$}} \\
\hline & & \\
\hline \multirow[t]{9}{*}{ Individual-team fit } & $\begin{array}{l}\text { professional and communication skills of } \\
\text { other team members }\end{array}$ & \\
\hline & \multirow[t]{2}{*}{ individual skills of team members } & dynamic team collaborations \\
\hline & & $\begin{array}{l}\text { overall virtual team work } \\
\text { experience }\end{array}$ \\
\hline & \multicolumn{2}{|l|}{$\begin{array}{l}\text { PM's efforts for matching individual } \\
\text { translation skills with project requirements }\end{array}$} \\
\hline & \multicolumn{2}{|l|}{ performance appreciation } \\
\hline & \multicolumn{2}{|l|}{ support from project management } \\
\hline & \multirow[t]{2}{*}{ Supervision } & effective supervision \\
\hline & & close supervision \\
\hline & \multicolumn{2}{|l|}{ Flexibility } \\
\hline \multirow[t]{3}{*}{$\begin{array}{l}\text { Individual-upper } \\
\text { management fit }\end{array}$} & $\begin{array}{l}\text { workflow management and business } \\
\text { processes }\end{array}$ & process standardisation \\
\hline & localisation maturity levels of client & $\begin{array}{l}\text { involvement of the PM in client } \\
\text { education }\end{array}$ \\
\hline & payment managements & payment terms \\
\hline \multirow[t]{2}{*}{ Individual-client } & client communication and relationship & $\begin{array}{l}\text { effective communication process } \\
\text { client expectations } \\
\text { maintaining respectful } \\
\text { relationships }\end{array}$ \\
\hline & client involvement & effective client review \\
\hline
\end{tabular}


Another possibility is that the same individual plays various roles in one work environment or works in several settings simultaneously. Thus, the perceived feeling of job satisfaction may represent the sum of feelings in several work settings and the undertaking of various roles in those settings. Since job satisfaction is bound to the work context, the aspects that contribute to satisfaction vary between translators working onsite or remotely. Likewise, organisational and team dynamics affect work behaviour of translators working onsite and those working as freelancers or sole proprietors. Job satisfaction refers to extrinsic sources of satisfaction, including the organisational and team dynamics as summarised in Table 2.

2.2.1 Individual-Job Fit. Individual-job fit focuses on the extent to which external sources of satisfaction or dissatisfaction meet individual expectations or needs that a translator has regarding his/her job. When individual expectations are aligned with what the job actually offers, the feeling of satisfaction increases. Individual-job fit includes the sources of satisfaction or dissatisfaction indicated in Table 2.

The job description of a translator has changed over the last two decades and these changes have been all the more acute for freelancers or translators working offsite. Salaried in-house translators generally work onsite, and although the nature of their job has also changed over the years, they are not typically required to possess such a high degree of specialisation or technical expertise as freelancers. Generally, in-house translators work in a hierarchical structure, having a supervisor or a coordinator with a regular schedule. The project coordinator reports to management and the translators are subject to evolving organisational and team dynamics. In contrast, freelancers follow the independent contractor model: they may be the owners of their business, may or may not have employees, work directly with the client, and generally work remotely. Freelancers may subcontract for LSPs as full-timers, or they may have a full-time in-house job. Freelancers working for LSPs are affected by team dynamics and may be subject to the organisational dynamics of the end client or the LSP, often teleworking or working from home. Some problems with teleworking in the LI are apparent in virtual teams, particularly due to problems with leadership and communication breakdowns. In online discussions on the ProZ.com platform, translators seem to agree that translation is becoming a stressful job with poor working conditions - for example, working overtime and over weekends has become widespread. The level of satisfaction is expected to vary with (i) processes in place; (ii) workload; and (iii) advantages or constraints related to being an in-house translator or a subcontractor.

Workload can be significantly influenced by the work environment. Salaried employees are not responsible for finding new clients or projects since their employer sets up a continuous stream of work, unless they are also performing sales-related tasks. Freelance translators, on the other hand, may not have a steady workload since they may be building their client portfolios, they may not have built a sales capacity, or they may be establishing contacts so as to market themselves to more clients and increase their workload to a level where their business becomes sustainable. Like other industries, the LI goes through cycles of high and low volumes of work during the year and during changing business cycles. Working for LSPs provides a translator with a higher level of security during periods of low work volume. McKay (2006, p. 63) argues that adapting to changing cycles may be "more of a psychological skill than a business one" but translators are advised to learn to anticipate the ups and downs of the market. Yet, as translators build long-term business relationships, they make themselves 
indispensable for some tasks or specific projects, thereby increasing their volume of work.

Remuneration refers to a monetary compensation received from accomplishing tasks in a specific work setting. Salary can be understood as a satisfier as well as a dissatisfier. Herzberg (1959) argues that it is closer to being a dissatisfier, "when salary occurred as a factor in the lows, it revolved around the unfairness ...of the wage system within the company," i.e., payment policies. By contrast, salary was considered a satisfier when studied as a form of achievement, or recognition, or "it meant more than money; it meant a job well done" (p. 83).

Deadlines have to be seen within the framework of project management process quality. Even though process quality will be discussed with the factors related to stakeholder satisfaction, it is important to state that process quality results from a combination of strategies related to successful project management, specifically planning and project coordination. Therefore, project management is a key component for successful project completion. Analysis of the variables - cost, quality and time - in the "triangle of objectives" (Lock, 2007) makes it apparent that the three elements are intertwined (Dunne 2011b, p. 120-21). Deadlines require a negotiation process with the client since speed to market is of paramount importance, and a trend has become apparent in deadlines getting tighter in the industry. Thus, deadlines are expected to be contributors to translator dissatisfaction.

Karatepe and Sokmen (2006) studied work-family conflict, and correlated emotional exhaustion with intrinsic motivation. They concluded that work-family conflict increased the feeling of emotional exhaustion and decreased satisfaction at work. In addition to satisfaction being influenced by the work/personal life balance, working onsite and offsite are expected to influence the responses of survey participants. Generally, translators and freelancers (salaried or not) are happy with working remotely, as they "experience greater job satisfaction and less stress" (McKay, 2006, p. 11) since working remotely is associated with an improved quality of life, reconciling a good work/personal life balance.

Lastly, job turnover has received significant attention in the literature (Lambert, Hogan, \& Barton, 2001; Mueller \& Price, 1990) and has been interpreted as a multifaceted construct. However, a simplistic approach has been taken in this study and turnover is understood as the intention to quit, which in turn is related to low job satisfaction.

2.2.2 Individual-Team Fit. Understanding the fit between an individual and the team becomes crucial because many satisfiers and dissatisfiers may emerge from these interactions. Table 2 illustrates potential sources of satisfaction as a result of team dynamics.

This study adopts a simplistic approach to the role of the project manager $(\mathrm{PM})$ and assumes that the PM is critical in team interaction. As the literature suggests, PMs can have a great impact on the performance of the team by facilitating team interaction as a channel of communication. The PM becomes the representative figure of organisational culture, the transmitter of the company's mission to team members and stakeholders. A PM's efforts to improve interpersonal relationships may result in workers showing a higher level of appreciation and respect for the PM, improving virtual team interactions (Aronson \& Lechler, 2003).

The critical factor, however, is "managing stakeholders' expectations through ongoing communication" (Stoeller, 2004, p. 3). PMs may be in charge of making policies and providing guidelines on the communication workflow, specific channels to be used, and the reporting structure. Hanna and Wilson (1991) argue 
that team satisfaction in a projectised business structure comes from (a) team members' perceptions concerning freedom to participate in the team (expectations); (b) team progress toward goals; and (c) a sense of belonging to the team (networking functions). A strong correlation is expected to develop, in which perceived satisfaction with the leader increases with well-planned and executed project management, and levels of satisfaction are expected to vary with translators working onsite or freelancing. This study focuses on the following main sources of satisfaction with respect to the PM's role: the individual level of satisfaction with communication workflow (Skansi, 2000), particularly in intercultural, virtual teams (Stoeller, 2011, p. 289-293), with the PM's efforts for matching individual translation skills with project requirements, with performance appreciation and initiative for labour force empowerment, with supervision, and translators' perceived feeling of support from the PM. In particular, the PM exhibits leadership skills in matching self-deployment and team deployment based on project requirements. Performance appreciation is related to task appreciation. Performance appreciation represents the efforts of a PM or a coordinator to motivate the team. Levels of expression of performance appreciation probably vary with an LSP's level of business maturity and investment in human capital. Providing feedback can also be considered an alternative form of appreciation for positive task performance. With regard to translator empowerment, freelancers generally have the freedom to choose the tasks or services they want to provide, so the chosen tasks are expected to be intrinsic motivators; this may not be an option for onsite translators. One way of giving autonomy to translators to increase their involvement is to let them select their teams and choose team partners, such as their favourite editors or terminologists. The PM's support or direct assistance is often critical in facilitating task completion on time and on budget. The PM's ability to provide direct assistance with job performance is assessed against the degree of availability of project resources or direct help with terminology queries or software troubleshooting.

Supervision is a concept that does not transfer directly to the LI. Close supervision may take place onsite, but in the subcontracting model, translators are expected to report progress themselves and supervision is not direct. Often, close supervision is tracked with the aid of technology via workflow management systems. Effective supervision is closely related to the PM's role and understanding of the translation process, with such leadership characteristics as exerting effective supervisory roles for intrinsic motivation (Deci \& Ryan, 1985; Hackman \& Oldham, 1976). Likewise, Kouzes and Posner (1987) emphasise that good interpersonal relationships emerge when a leader provides the follower with a supervisory context that is motivational, enabling him/her to be more effective (Chemers, 2002).

Individual-team fit further studies the role of the project manager vis-à-vis interpersonal relationships and overall experience of working with virtual teams. Even though these concepts are crucial for the creation of a dynamic collaborative work environment onsite or offsite, these concepts have not been included in this study for the sake of brevity (for further discussion, see Rodríguez-Castro, 2013).

Additionally, flexibility has become a professional attribute that translators must possess for successful virtual teamwork. The lack of flexibility in any team member impacts team cohesion and relationships, thus potentially increasing dissatisfaction. Lastly, translators in virtual teams rarely experience face-to-face interaction because of the high cost of travel (Stoeller, 2011, p. 292), resulting in constraints for developing team cohesion. 
2.2.3 Individual-Upper Management Fit. Individual-upper management fit investigates the main sources of satisfaction or dissatisfaction that are influenced by organisational dynamics related to upper management. The individual translator is generally impacted by upper management in the form of business and workflow management processes. The more effective and clear the processes, the greater the level of satisfaction from this source is expected to be. The concepts investigated in this section are listed in Table 2.

Workflow management and business processes consist of various issues that impact satisfaction, including quality control and quality assurance management. Workflow management is understood as the overall approach adopted by a translation company to handle the entire translation process, while business processes involve the adoption of systems of practice that facilitate the facets such as planning and execution (Turner, 2006). According to the industry standard ASTM F 2575 (2006), the translation supply chain consists of multiple stakeholders: end user, requester, project manager, translator, editor, etc. However, the roles and the sequences may vary from one LSP to another. Established processes to deal with client consultation, client acceptance and communication (Pinto \& Slevin, 1988), for instance, as well as the ability to handle conflicts and information (Lechler, 1998) are some key factors of business that play a key role in business processes. Lastly, Porskrog (2008, p. 30) summarises the factors that could ensure smooth project execution and includes the notion of "well established processes" to manage projects (Cooke-Davies, 2001; Andersen \& Jessen, 2003). In this study, a higher level of job satisfaction is expected to be found in translators working with providers who prioritise the implementation of formal business processes and effective workflows. Nevertheless, depending on the work setting, the PM may or may not have an active role in workflow management. In fact, translator satisfaction with workflow management varies with the perceived efficacy of the PM in dealing with workflow issues.

Localisation maturity levels are indirectly associated with workflow management efficacy and organisational efforts to improve processes, and can vary significantly from one LSP to another. Research conducted by Common Sense Advisory (DePalma et al.) defines the Localisation Maturity Model (LMM) as an approach to assess and document "the behaviours, processes, and activities that constitute defined, managed, and repeatable best practices" (2006, p. 1). LSPs at higher levels of maturity are expected to implement processes to facilitate communication workflow with the end client. Generally, the level of company maturity can be directly reflected in the effectiveness of the PM in dealing with end client interactions. Hence, it is expected that the higher the level of company maturity and commitment to process improvement and efficiency, the greater the involvement of the PM in client education and the more successful the PM's interaction with the client will be, resulting in enhanced translator job satisfaction.

The last concept of interest is payments. Payment practices and terms vary with the service provider's line of credit. Depending on the line of credit, subcontractors may get paid by the translation company even if the client has not paid the company. LSPs without a line of credit will not pay the translator until the client pays the LSP. Translation agencies may also have their own payment terms, and these terms are not negotiable. Often, the terms may indicate that payment will be issued within 30 days of invoicing (McKay, p. 29). Sometimes payment terms may stipulate that the payment will be issued after 60 days or even after 90 days. The literature suggests that up-front payments do not seem to be common in the LI (Durban, p. 187). Generally, subcontractors are increasingly 
dissatisfied with payment practices and terms when working for LSPs. By contrast, payment terms are usually fixed for salaried translators (paid at the end of the month, or biweekly).

2.2.4 Individual-Client Relationship. Organisational support from the end client or end user is expected to vary with the end client's commitment to stakeholder satisfaction. In this section, end client's level of understanding of the translation process and the level of involvement in stakeholder satisfaction are captured and summarised in Table 2.

Based on an end client's initial level of understanding of the translation process, greater efforts by the translation company and the PM to educate clients and establishing a standardised client communication process may be necessary for satisfactory interaction. Regarding client involvement, ASTM F 2575 establishes guidelines for smooth relationships between the requester and the translation provider and recommends that the translator's questions should be answered before the project is initiated. Dunne (2011c) highlights the role, continual feedback and active participation of (a) the end client; (b) client reviewers; and (c) the end user in order to successfully implement a customerfocused approach that prioritises stakeholder satisfaction (p. 183). Both in-house and freelance translators can derive job satisfaction from a smooth client communication process.

In addition to effective communication workflow, client review seems to be the most common form of client involvement in the translation process. Effective client review is a clear manifestation of good communication between translation buyers and service providers. The review process should be used as an opportunity by vendors to receive valuable feedback and improve relationships with customers by implementing suggestions and making changes, wherever and whenever necessary. Moreover, client review often offers an opportunity to improve business, quality and workflow processes and to educate the client. Conversely, client review may be seen as a source of dissatisfaction by translators, especially when disagreements emerge. Durban (2010, p. 60) presents the example of the reaction of an unhappy translator to client feedback to his work. According to the author, translators should be grateful to receive feedback, and should use the opportunity to increase their contacts. Detailed client reviews and feedback on translation samples may be interpreted as opportunities to learn.

\section{Method}

Key concepts discussed in the previous section have been selected and identified for the construct of translator satisfaction and may be grouped together in two main categories: task and job satisfaction. In this study the two categories are assessed by means of an online questionnaire for data collection.

A pilot study was conducted in October 2010 during the American Translators Association (ATA) Annual Conference (held in Denver, Colorado) in order to assess the viability of some of the concepts in the questionnaire. The participants $(\mathrm{N}=25)$ were active translation professionals, mostly with 10 or more years of job experience, so the pilot study results were biased. However, the pilot study provided the opportunity to establish initial contacts with some translation professionals and obtain preliminary feedback for the development of the final instrument.

From the pilot study, it was evident that questions suggesting a ranking or order of priority in the response were ambiguous. In addition, expressions related 
to business or the industry such as business capabilities or localisation maturity were confusing. Many freelancers mentioned that they do not work in teams, and most of the questions about teamwork had to be refined. Questions in the final instrument were proofread and screened for ambiguity, complex terminology and redundancy by three experts. Approval was obtained from the Institutional Review Board (IRB) for the Protection of Human Subjects at Kent State University.

A comprehensive survey was designed to gather relevant data about individual attitudes toward satisfaction, and to identify aspects that influence translators' sources of satisfaction and dissatisfaction. The instrument development, data collection process and data analysis methods proposed in this study are detailed in the remaining part of this section.

\subsection{Instrument Development - Measures}

The two most common approaches used in the literature for measuring satisfaction can be classified as (1) measurements of overall satisfaction and (2) measurements of subcomponents of satisfaction. "Overall work satisfaction is likely to reflect the combination of partial satisfactions related to various features of one's job" (Skalli, Theodossiou \& Vasileiou, 2008, p. 1906), such as remuneration, job security and working hours. The level of overall job satisfaction can be considered a weighted result of the aggregated feelings of individual satisfaction relating to each of the individual aspects. The conclusion that the level of overall work satisfaction depends on the need for evaluating individual subcomponents has been supported by some researchers (Frey \& Stutzer, 2002). However, other researchers contend that individuals should make a judgment about their jobs as a whole (Skalli, Theodossiou \& Vasileiou, 2008). However, it may be noted that the literature on satisfaction supports the relevance of measuring subcomponents of satisfaction indirectly.

Although internal criterion scales (rated scales) have become the most widely implemented means of measurement, the two best-known scales for measuring subcomponents of (job) satisfaction are the Job Descriptive Index (JDI) and the Minnesota Satisfaction Questionnaire (MSQ). Both instruments have gained wide recognition among researchers and have been replicated in numerous studies on satisfaction. Even though an approach of measuring the subcomponents of satisfaction has been adopted in this study, these instruments could not be used to measure translator satisfaction since most of the sources of satisfaction cannot be directly transferred to the dynamic work environments widely prevalent in the LI. The proposed instrument uses a combination of direct and indirect methods, as suggested in current research so as to assess the level of satisfaction of participants. A five-point Likert scale (Likert, 1932) has been adopted in this study to measure the levels of satisfaction with respect to each item listed in the survey. This allows for quantifying the responses of each participant, and these responses can be compared and parsed for interpretation and for statistical analysis. A 1-5 Likert scale is a direct measurement, whereas using items that imply dissatisfaction (e.g., turnover) can be used as an indirect measure of satisfaction. The five-point Likert scale ranges from a minimum of 1 , assigned to strongly agree or very satisfied, to a maximum of 5, assigned to strongly disagree or very dissatisfied. In addition, qualitative data has also been gathered from selfreporting, open-ended answers. Open-ended questions are included so that participants can elaborate on their responses. Nevertheless, the number of openended questions is minimised to limit the time required and reduce participant fatigue. Note that specific questions have been used in the survey to directly 
measure the overall feeling of satisfaction for each category for benchmarking purposes.

Currently, no tool used for assessing translator satisfaction offers the level of granularity provided by the instrument proposed in this paper. The instrument presents a novel and rigorous way of comprehending the contribution of specific factors to two categories of translator satisfaction: task and job.

\subsection{Instrument Design}

The questionnaire used for this study has been divided into two main sections: (1) Demographics and Professional Profile and (2) Translator Satisfaction Index.

3.2.1 Demographics and Professional Profile. The first section of the questionnaire includes the following items:

(a) Demographic variables such as age, gender, income range, etc;

(b) Formal education, measured with two variables: the first survey item captures formal education related to Translation Studies, and the second captures non-translation degrees of translation professionals. Formal education also includes the level of education (master's degree, bachelor's degree, professional degree) achieved. Professional certifications include certifications in legal translation, localisation, etc.;

(c) Job experience as measured by years of experience and/or by number of years in business, or working for an employer, years working for favourite clients;

(d) Specialisation (area of specialisation, number of areas) or subject matter expertise. Participants are asked to select all applicable areas of specialisation from the following: commercial or business, diplomatic, financial, journalistic, legal (patents, government), manufacturing, marketing, tourism, medical, pharmaceutical, audiovisual, software translation, videogames, gambling, IT, technical/scientific, literary, international affairs, education, history, and social sciences. Participants are also asked to specify whether they have worked in other domains;

(e) Technical expertise, certifications, specific training and knowledge of CAT tools, services offered (terminology management, translation, proofreading, etc.), level of familiarity with certain CAT tool formats and input files. Table A.1 in the Appendix shows a portion of the instrument used for assessing technical expertise;

(f) Work environment helps in understanding whether the translation professional is salaried working remotely, salaried in-house, a freelancer or a subcontractor or working in-house. In addition, translators are asked whether they are registered as sole proprietors, with or without employees;

(g) Specific roles in the industry (one may choose more than one option, if applicable) based on the services offered (translation, editing, proofreading, postediting, terminology management, desktop publishing software engineering-related activities, etc.);

(h) Constant or episodic: Respondents are asked to identify whether their work in the language industry is sporadic or regular;

(i) Workload, measured in annual volume, translated words per day and number of hours worked per week during active periods of work. The participants are classified into part-timers (5-20) or full-timers (21-80) based on the number of hours worked per week. 
3.2.2 Translator Satisfaction Index. The second section of the questionnaire assesses the theoretical construct for translator satisfaction through the task and job satisfaction indices discussed in Sections 2.1 and 2.2. These indices measure key sources of satisfaction or dissatisfaction through the items listed in the questionnaire. Tables A.1, A.2 and A.3 in the Appendix provide excerpts of the questionnaire pertaining to task satisfaction and job satisfaction respectively.

\subsection{Data Collection Procedure}

Final data collection was started after IRB approval in February 2011. Data was collected by means of a questionnaire that was posted online using the Qualtrics software application. Participants were sent an invitation (recruitment message) via email. The first page of the survey contained the consent form, which explained the nature of the questionnaire, main research goals and participation expectations. After signing the informed consent form, participants could start answering the questions. Participants were also made aware of the benefits and risks of participation and were informed that their answers would be anonymous. It may be noted that participation in this study was entirely voluntary and that the participants were not compensated for their time.

The selection of the survey participants was as arbitrary as possible. The survey was advertised via worldwide translation email lists (ATISA, CETRA, etc.) and translation portals such as Proz.com and TranslatorsCafe.com. Some translators were contacted at email addresses obtained from national and international professional associations. All these means of communication proved to be effective and yielded participants from many countries with wide-ranging specialisations, thereby making a strong case for the sample representativeness of the survey.

Several trials of the survey questionnaire were conducted online in order to ensure the proper functioning of the software. Based on data obtained during the trials, the questionnaire was expected to take approximately 30 minutes to complete. Translators were given up to two months to complete the questionnaire. The online survey questionnaire was completed by 250 participants. All the participants were active translation professionals with a wide variety of job profiles and professional experiences.

\subsection{Instrument Validity}

The content validity of the final instrument designed for this study was tested during a pilot study. Validity of results has been enhanced by repeated use of direct as well as indirect questions in the survey and the use of indirect measures of satisfaction.

The Cronbach alpha is a coefficient of reliability used to measure the internal consistency of a test score for a sample of data collected from a survey and is often used in social sciences. The value varies between 0 and 1: the higher the value, the better the instrument validity is considered to be.

The Cronbach alpha coefficient for the entire instrument has been calculated as 0.98 . Cronbach alpha coefficients have also been separately computed for the portions of the survey pertaining to task satisfaction and job satisfaction, and the values are 0.80 and 0.92 respectively. This calculation will be repeated after completion of the data collection process in order to verify the validity of the final instrument. The validity of the instrument will be further tested during postprocessing of the results. Initial results from the pilot study indicate that task pride and ability to perform a variety of tasks are identified as major sources of task satisfaction. Additionally, some sources of job satisfaction identified from the pilot study are the professional skills of team members and clients' understanding 
of the overall translation process. These results are preliminary and will be further investigated and reported in a future study. It is acknowledged that generalising the findings from a survey instrument is extremely challenging. However, a high level of participation from active industry professionals and a rigorous statistical analysis can be expected to yield results that may enhance an understanding of the translation profession.

\section{Conclusion and Future Scope}

This paper presents a detailed instrument that can be used to gauge translator satisfaction. The main contribution of this study is the creation of a rigorous instrument that is capable of assessing the main sources of satisfaction and dissatisfaction in the current LI. The instrument proposed in this paper measures direct and indirect task and job satisfiers and dissatisfiers. The design of a reliable instrument for data collection is a daunting task since very few instruments for measuring satisfaction in the LI have hitherto been developed. This is especially important to comprehend the challenges of emerging trends such as outsourcing and dynamic work environments that have significantly reshaped the translation process.

The main drawback of the instrument proposed in this study is its length. Even though some motivators are inserted at three stages of the survey, the length of the survey could reduce the rate of participation. No instrument of this kind has been developed for translator satisfaction, and there is a lack of an empirical foundation that can be used to comprehensively understand the sources of satisfaction or dissatisfaction among translation professionals. Therefore, the length of the survey has been deemed to be appropriate in order to ensure a successful data collection process that can be used as a baseline for future studies.

It is acknowledged that survey participants could have been given a not applicable option for many questions, given the diversity of work environments in the current language industry. Making the selections mandatory facilitates postprocessing of the data and maintains the 1-5 numerical scale, allowing a quantitative analysis of the responses. The choice of the five-point Likert scale has proven to be useful since it provides the participants with a neutral choice in the form of scale item 3 and compensates for the lack of a not applicable option in the survey. It may be noted that a 1-3 Likert scale was used in the pilot study but was found to be problematic because it limited the range of options for respondents.

Descriptive and inferential statistical analysis will be used to post-process the data collected from the survey as part of future scope. In particular, hypothesis testing, correlation analysis and linear regression will be used to analyse the data. The data collected from this study can also be used to enhance the understanding of relationships or interdependencies in the form of a model in order to establish predictive relationships among the concepts. Furthermore, key differences in work behaviour between experts and novices, or between in-house and subcontracting translators, will be explored in future studies. This is expected to lead to a broad understanding of the sources of satisfaction and dissatisfaction among active translators working in very diverse work environments. 


\section{References}

Ammons, R. B. (1956). Effects of Knowledge of Performance: A Survey and Tentative Theoretical Formulation. Journal of General Psychology, 54, 279-299.

Andersen, E. S., \& Jessen, S. A. (2003). Project Maturity in Organisations. International Journal of Project Management. 21(6), 457-461.

Aronson, Z., \& Lechler, T. (2003). Project Success: The Role of Project Morale. Paper presented at the Annual Conference of the Society for Industrial Organizational Psychology, Orlando, Florida, April 03.

ASTM Standard F2575, (2006). Standard Guide for Quality Assurance in Translation. ASTM International, West Conshohocken, PA, 2006. DOI: 10.1520/C0033-03R06. Retrieved from http://www.astm.org/Standards/F2575.htm.

Bandura, A. (1995). Self-Efficacy in Changing Societies. Cambridge; New York: Cambridge University Press.

Chemers, M. (2002). Efficacy and Effectiveness: Integrating Models of Leadership and Intelligence. In S. Ott, S. J. Parkes, \& Simpson, R. B. (Eds.), Classic Readings in Organizational Behavior (pp. 114-231). 3rd ed. Belmont, CA: Thomson/Wadsworth.

Cooke-Davies, T. J. (2001). Towards Improved Project Management Practice: Uncovering the Evidence for Effective Practices through Empirical Research (Doctoral dissertation, Leeds Metropolitan University, United Kingdom). Retrieved from http://www.dissertation.com/book.php?method=ISBN\&book=1581121288.

Dam, H. V., \& Zethsen, K. K. (2009). Who said low status? A study on factors affecting the perception of translator status. The Journal of Specialised Translation, 12, 2-36.

Dam, H. V., \& Zethsen, K. K. (2011). The Status of Professional Business Translators on the Danish Market: A Comparative Study of Company, Agency and Freelance Translators. Meta: Translators' Journal, 56(4), 976-997.

Deci, E. L., \& Ryan, R.M. (1985). Intrinsic Motivation and Self-determination in Human Behavior. New York: Plenum.

DePalma, D., Beninatto, R. S., \& Sargent, B. B. (2006). Localization Maturity Model. Chelmsford, Massachusetts: Common Sense Advisory. Retrieved from http://www.commonsenseadvisory.com/AbstractView.aspx?ArticleID=959.

DePalma, D. A., \& Beninatto R. S. (2008). Localization Vendor Management. Best Practices for Managing Language Service Providers. Chelmsford, Massachusetts: Common Sense Advisory. Retrieved from http://www.commonsenseadvisory.com/Default.aspx? Contenttype $=$ ArticleDet\&tabID $=64 \&$ moduleId $=392 \& A i d=1111 \& P R=P R$.

DePalma, D. A., Hegde, V., \& Pielmeier H. (2014). The Language Services Market: 2014. Chelmsford, Massachusetts: Common Sense Advisory. Retrieved from $\mathrm{http}: / /$ www.commonsenseadvisory.com/AbstractView.aspx?ArticleID $=21531$.

Douthitt, E. A., \& Aiello, J. R. (2001). The Role of Participation and Control in Effects of Computer Monitoring on Fairness Perceptions, Task Satisfaction, and Performance. Journal of Applied Psychology, 86(5), 867-874.

Dunne, K. J. (2011a). Integrating Project Management into Translation Curricula: The Kent State University Experience. In P. A. Schmitt, S. Herold, \& A. Weilandt (Eds.), Translationsforschung. Tagungsberichte des LICTRA 2010 IX. Vol. 1. (pp. 183-195). Frankfurt am Main, Berlin, Bern, Bruxelles, New York, Oxford, Wien: Peter Lang.

Dunne, K. J. (2011b). Project Time Management in Translation and Localization. In K. J. Dunne, \& E. S. Dunne (Eds.), Translation and Localization Project Management: The Art of the Possible (pp. 119-152). Amsterdam; Philadelphia: John Benjamins.

Dunne, K. J. (2011c). Customer-focused Quality Management using ISO and Agile. In K. J. Dunne, \& E. S. Dunne (Eds.), Translation and Localization Project Management: The Art of the Possible (pp. 153-187). Amsterdam; Philadelphia: John Benjamins.

Dunne, K. J. (2012). The industrialization of translation: Causes, consequences and challenges. Translation Spaces, 1, 143-68.

Durban, C. (2010). The Prosperous Translator. Raleigh, North Carolina: Lulu.

Ehrensberger-Dow, M., \& Massey G. (2014). Translators and machines: Working together. In Man vs. Machine? Vol.1. Proceedings of XXth World Congress of the International Federation of Translators. Berlin: BDÜ Fachverlag, 2014. 199-207. 
Fisher, C. D. (1980). On the Dubious Wisdom of Expecting Job Satisfaction to Correlate with Performance. Academy of Management Review, 5(4), 607-612.

Frey, B., \& Stutzer, A. (2002). The Economics of Happiness. World Economics, 3(1), 117.

Fried, Y., \& Ferris, G. R. (1987). The Validity of the Job Characteristics Model: A Review and Meta-Analysis. Personnel Psychology, 40(2), 287-322.

García, I. (2009). Beyond Translation Memory: Computers and the Professional Translator. The Journal of Specialised Translation, 12, 199-214.

Goldstein, K. (1939). The Organism, a Holistic Approach to Biology Derived from Pathological Data in Man. New York; Cincinnati: American Book Company.

Hackman, R. J., \& Oldham, G. R. (1976). Motivation Through the Design of Work: Test of a Theory. Organizational Behavior and Human Performance, 16, 250-279.

Hanna, M. S., \& Wilson, G. L. (1991). Communicating in Business and Professional Settings. New York: McGraw-Hill.

Herzberg, F. (1959). The Motivation to Work. New York: John Wiley \& Sons.

Herzberg, F.. (January 01, 2003). One more time: how do you motivate employees? 1968. Harvard Business Review, 81(1), 87-96.

Jawahar, I. M. (2006a). Correlates of satisfaction with performance appraisal feedback. Journal of Labor Research, 27(2), 213-236.

Jawahar, I. M.. (2006b). An investigation of potential consequences of satisfaction with appraisal feedback. Journal of Leadership \& Organizational, 13(2), 14-28.

Karatepe, O. M., \& Sokmen, A. (2006). The Effects of Work Role and Family Role Variables on Psychological and Behavioral Outcomes of Frontline Employees. Tourism Management, 27(2), 255-268.

Kelly, N., \& Stewart, R. G. (2010). The Top 35 Language Service Providers. Lowell, MA: Common Sense Advisory.

Kelly, N.. (2014). Why so Many Translators Hate Translation Technology. The Huffington Post. Retrieved from http://www.huffingtonpost.com/nataly-kelly/why-so-manytranslators-h_b_5506533.html.

Klein, J. A. (1989). The Human Costs of Manufacturing Reform. Harvard Business Review, 67(2), 60-66.

Koriat, A. (1993). How do we Know that we Know? The Accessibility Model of the Feeling of Knowing. Psychological Review, 100(4), 609-639.

Kouzes, J. M., \& Posner, B. Z. (1987). The Leadership Challenge: How to Get Extraordinary Things Done in Organizations. San Francisco: Jossey-Bass.

Kuznik, A., \& Verd, J. M. (2010). Investigating Real Work Situations in Translation Agencies. Work Content and its Components. Hermes - Journal of Language and Communication Studies, 44, 25-43.

Lambert, Z. V., \& Durand, R. M. (1975). Some Precautions in Using Canonical Analysis. Journal of Market Research, 12(4), 468-475.

Lambert, E. G., Hogan, N. L., and Barton, S. M. (2001). The Impact of Job Satisfaction on Turnover Intent: a Test of a Structural Measurement Model Using a National Sample of Workers. The Social Science Journal, 38(2), 233-250.

Lechler, T. (1998). "When it Comes to Project Management, it's the People that Matter: An Empirical Analysis of Project Management in Germany." In F. Hartman, G. Jergeas, \& J. Thomas (Eds.), Proceedings of the IRNOP III Conference -The Nature and Role of Projects in the Next 20 Years: Research Issues and Problems. (IRNOP III Conference, Calgary, 07-98). Calgary: Project Management Specialization, University of Calgary.

Lee, C. D. (2006). Feedback, Not Appraisal. HR Magazine: Management Tools, 51(11), 111-114.

Likert, R. (1932). A Technique for the Measurement of Attitudes. Archives of Psychology, 22(140), 1-55.

Lock, D. (2007). Project Management. Aldershot, England: Gower.

Locke, E. A. (1976). The Nature and Causes of Job Satisfaction. In M. D. Dunnette, L.M. Hough, \& H.C. Triandis (Eds.), Handbook of Industrial and Organizational Psychology (pp. 1297-1349). Chicago, IL: Rand McNally.

Locke, E. A., \& Latham, G. P. (1990). A Theory of Goal Setting and Task Performance. Englewood Cliffs, New Jersey: Prentice Hall.

Translation \& Interpreting Vol 7 No 2 (2015) 
Maslow, A. H. (1954). Motivation and Personality. New York: Harper.

Mason, C.M., and Griffin, M. A. (2002). Group Task Satisfaction: Applying the Construct of Job Satisfaction to Groups. Small Group Research, 33, 271-312.

McKay, C. (2006). How to Succeed As a Freelance Translator. New York: Two Rat Press.

Metcalfe, J., Schwartz, B. L., \& Joaquim S.G. (1993). The Cue Familiarity Heuristic in Metacognition. Journal of Experimental Psychology: Learning, Memory and Cognition, 19(4), 851-861.

Mueller, C. W., \& Price, J. L. (1990). Economic, Psychological, and Sociological Determinants of Voluntary Turnover. Journal of Behavioral Economics, 19, 321335.

PACTE. (2011). Results of the Validation of the PACTE Translation Competence Model: Translation Problems and Translation Competence. In C. Alvstad, A. Hild, \& E. Tiselius (Eds.), Methods and Strategies of Process Research: Integrative Approaches in Translation Studies (pp. 317-343). Amsterdam: John Benjamins.

Pinto, J. K., \& Slevin, D. P. (1988). Critical Success Factors across the Project Life Cycle. Project Management Journal, 19(3), 67-75.

Porskrog, S. (2008). Project and Project Management Success Criteria and Factors. Project Manager Today. October 2008, 30-31.

ProZ.com. The translation workplace. (n.d.). Retrieved from http://www.proz.com/

Robinson, D. (1997). Becoming a Translator: An Accelerated Course. London; New York: Routledge.

Rodríguez-Castro, M. (2013). The project manager and virtual translation teams: Critical factors. Translation Spaces, 2, 37-62.

Shreve, G. M. (2002). Knowing Translation: Cognitive and Experiential Aspects of Translation Expertise from the Perspective of Expertise Studies. In A. Riccardi (Ed.), Translation Studies. Perspectives on an Emerging Discipline (pp. 150-171). Cambridge: Cambridge University Press.

Shreve, G. M. (2009). Recipient-Orientation and Metacognition in the Translation Process. In R. Dimitriu (Ed.), Translators and their Readers. In Homage to Eugene A. Nida (pp. 255-270). Brussels: Les Editions du Hasard.

Shreve, G. M., \& Angelone, E. (2010). Translation and Cognition. Amsterdam; Philadelphia: John Benjamins.

Skalli, A., Theodossiou, I., \& Vasileiou, E. (2008). Jobs as Lancaster Goods: Facets of Job Satisfaction and Overall Job Satisfaction. Journal of Socio-economics, 37(5), 19061920.

Skansi, D. (2000). Relations of Managerial Efficiency and Leadership Styles - Empirical Study, Hrvatska elektroprivreda. Management, 5(2), 51-67.

Stoeller, W. (Apr/May 2004). Guide to Project Management. Multilingual Computing \& Technology. Vol. 63. Supplement, 3-6.

Stoeller, W. (2011). Global Virtual Teams. In K. J. Dunne, \& E. S. Dunne (Eds.), Translation and Localization Project Management: The Art of the Possible (pp. 290347). Amsterdam; Philadelphia: John Benjamins.

Turner, R. J., \& Müller, R. (2006). Choosing Appropriate Project Managers: Matching Their Leadership Style to the Type of Project. Newtown Square, PA: Project Management Institute. 


\section{Appendix}

Table A.1 - Assessment of Technical expertise.

\begin{tabular}{|c|c|c|c|c|c|}
\hline \multicolumn{5}{|l|}{ Question } & Answers \\
\hline \multirow{2}{*}{\multicolumn{5}{|c|}{ Do you use CAT tools (TM, termbase, etc.)? }} & Yes \\
\hline & & & & & No \\
\hline \multirow{2}{*}{\multicolumn{5}{|c|}{ Do you have specific training on CAT tools (i.e. TM, terminology management, etc)? }} & Yes \\
\hline & & & & & No \\
\hline \multirow{2}{*}{\multicolumn{5}{|c|}{ Are you planning on earning more certifications? }} & Yes \\
\hline & & & & & No \\
\hline \multirow{2}{*}{\multicolumn{5}{|c|}{ Do you feel that your studies have developed your CAT-tool knowledge? }} & Yes \\
\hline & & & & & No \\
\hline \multirow{2}{*}{\multicolumn{5}{|c|}{ Do you feel that your studies have developed your terminology skills? }} & Yes \\
\hline & & & & & No \\
\hline \multicolumn{6}{|c|}{ Which tools do you use in the tasks that you perform? } \\
\hline \multicolumn{6}{|c|}{ How familiar are you with the following file formats? } \\
\hline File NAME & Very familiar & $\begin{array}{l}\text { Somewhat } \\
\text { familiar }\end{array}$ & $\begin{array}{l}\text { Neither familiar } \\
\text { nor ignorant }\end{array}$ & $\begin{array}{l}\text { Somewhat } \\
\text { ignorant }\end{array}$ & No idea \\
\hline \multicolumn{6}{|l|}{ CSV } \\
\hline \multicolumn{6}{|l|}{ TMX } \\
\hline \multicolumn{6}{|l|}{ TBX } \\
\hline \multicolumn{6}{|l|}{ XLIFF } \\
\hline \multicolumn{6}{|l|}{ DITA } \\
\hline \multicolumn{6}{|c|}{ How familiar are you with the following source files? } \\
\hline File NAME & Very familiar & $\begin{array}{l}\text { Somewhat } \\
\text { familiar }\end{array}$ & $\begin{array}{l}\text { Neither familiar } \\
\text { nor ignorant }\end{array}$ & $\begin{array}{l}\text { Somewhat } \\
\text { ignorant }\end{array}$ & No idea \\
\hline \multicolumn{6}{|l|}{ DOC } \\
\hline \multicolumn{6}{|l|}{ HPR or HPJ } \\
\hline \multicolumn{6}{|l|}{ PSD } \\
\hline \multicolumn{6}{|l|}{ XML } \\
\hline \multicolumn{6}{|l|}{ INX } \\
\hline \multicolumn{6}{|l|}{ PPT } \\
\hline \multicolumn{6}{|l|}{ TOC } \\
\hline \multicolumn{6}{|l|}{ XLS } \\
\hline \multicolumn{6}{|l|}{ DWG } \\
\hline DXF & & & & & \\
\hline
\end{tabular}


Table A.2 - Assessment of Task Satisfaction (excerpt).

\begin{tabular}{|c|c|c|c|c|c|}
\hline Question & $\begin{array}{l}\text { Very much } \\
\text { agree }\end{array}$ & $\begin{array}{l}\text { Agree } \\
\text { moderately }\end{array}$ & $\begin{array}{l}\text { Neither agree } \\
\text { nor disagree }\end{array}$ & $\begin{array}{l}\text { Disagree } \\
\text { moderately }\end{array}$ & $\begin{array}{l}\text { Very } \\
\text { much } \\
\text { disagree }\end{array}$ \\
\hline $\begin{array}{l}\text { I feel I am too slow and that } \\
\text { I should be working faster }\end{array}$ & 0 & O & O & O & 0 \\
\hline $\begin{array}{l}\text { Knowledge of CAT tools is } \\
\text { essential to meet my } \\
\text { deadlines }\end{array}$ & O & O & O & $\bigcirc$ & O \\
\hline $\begin{array}{l}\text { I feel that deadlines do not } \\
\text { compromise quality }\end{array}$ & $\bigcirc$ & 0 & $\bigcirc$ & 0 & 0 \\
\hline $\begin{array}{l}\text { My subject matter expertise } \\
\text { helps me meet deadlines }\end{array}$ & 0 & 0 & O & O & O \\
\hline $\begin{array}{l}\text { Task description shows } \\
\text { accurate nature of work }\end{array}$ & $\bigcirc$ & 0 & 0 & 0 & 0 \\
\hline $\begin{array}{l}\text { Terminological complexity } \\
\text { stress me out }\end{array}$ & 0 & 0 & $\bigcirc$ & 0 & O \\
\hline Question & $\begin{array}{l}\text { Very } \\
\text { satisfied }\end{array}$ & $\begin{array}{l}\text { Somewhat } \\
\text { satisfied }\end{array}$ & $\begin{array}{l}\text { Neither satisfied } \\
\text { nor dissatisfied }\end{array}$ & $\begin{array}{l}\text { Somewhat } \\
\text { dissatisfied }\end{array}$ & $\begin{array}{l}\text { Dissatisfi } \\
\text { ed }\end{array}$ \\
\hline $\begin{array}{l}\text { My ability to perform a wide } \\
\text { variety of tasks }\end{array}$ & 0 & $\bigcirc$ & 0 & $\bigcirc$ & 0 \\
\hline $\begin{array}{l}\text { Working on the tasks of my } \\
\text { specialization }\end{array}$ & 0 & 0 & 0 & 0 & $\bigcirc$ \\
\hline Quality of the source text & 0 & 0 & O & 0 & 0 \\
\hline $\begin{array}{l}\text { Working on challenging and } \\
\text { complex tasks }\end{array}$ & O & 0 & O & 0 & O \\
\hline $\begin{array}{l}\text { Responsibilities associated } \\
\text { with your role }\end{array}$ & O & $\bigcirc$ & 0 & 0 & O \\
\hline $\begin{array}{l}\text { Level of autonomy given to } \\
\text { make decisions }\end{array}$ & $\bigcirc$ & 0 & 0 & 0 & 0 \\
\hline $\begin{array}{l}\text { Feedback on translation } \\
\text { samples }\end{array}$ & 0 & $\bigcirc$ & $\bigcirc$ & $\bigcirc$ & $\bigcirc$ \\
\hline Question & Very likely & Likely & $\begin{array}{l}\text { Moderately } \\
\text { likely }\end{array}$ & Unlikely & $\begin{array}{l}\text { Very } \\
\text { unlikely }\end{array}$ \\
\hline $\begin{array}{l}\text { How likely is it that you will } \\
\text { take new roles or new tasks } \\
\text { in a completely new working } \\
\text { environment? }\end{array}$ & 0 & 0 & $\bigcirc$ & 0 & 0 \\
\hline
\end{tabular}


Table A.3 - Assessment of Job Satisfaction (excerpt).

\begin{tabular}{|c|c|c|c|c|c|}
\hline Question & $\begin{array}{l}\text { Very } \\
\text { much } \\
\text { agree }\end{array}$ & $\begin{array}{l}\text { Agree } \\
\text { moderately }\end{array}$ & $\begin{array}{l}\text { Neither } \\
\text { agree nor } \\
\text { disagree }\end{array}$ & $\begin{array}{l}\text { Disagree } \\
\text { moderately }\end{array}$ & $\begin{array}{l}\text { Very } \\
\text { much } \\
\text { disagree }\end{array}$ \\
\hline $\begin{array}{l}\text { I feel that my voice is heard within } \\
\text { the team }\end{array}$ & $\bigcirc$ & O & $\bigcirc$ & O & O \\
\hline Team work stresses me out & 0 & 0 & 0 & 0 & 0 \\
\hline Deadlines often too tight & 0 & 0 & 0 & 0 & 0 \\
\hline $\begin{array}{l}\text { I can choose the team with whom I } \\
\text { want to work }\end{array}$ & 0 & 0 & 0 & 0 & 0 \\
\hline $\begin{array}{l}\text { I feel I improve the quality of the } \\
\text { whole project }\end{array}$ & O & O & O & $\bigcirc$ & $\bigcirc$ \\
\hline $\begin{array}{l}\text { Usually misunderstandings with } \\
\text { PM and team members are solved } \\
\text { quickly, smoothly, and efficiently }\end{array}$ & ○ & $\bigcirc$ & $\bigcirc$ & $\bigcirc$ & O \\
\hline $\begin{array}{l}\text { In most LSPs, the } \\
\text { translation/localization process is } \\
\text { systematised }\end{array}$ & $\bigcirc$ & O & O & O & O \\
\hline $\begin{array}{l}\text { I can afford to choose with whom I } \\
\text { work (e.g. agencies) }\end{array}$ & 0 & ○ & $\bigcirc$ & $\bigcirc$ & $\bigcirc$ \\
\hline $\begin{array}{l}\text { Client does not understand the } \\
\text { translation/localization process }\end{array}$ & $\bigcirc$ & O & $\bigcirc$ & $\bigcirc$ & O \\
\hline $\begin{array}{l}\text { My relationship with the client is } \\
\text { continuous and respectful }\end{array}$ & O & $\bigcirc$ & O & 0 & $\bigcirc$ \\
\hline $\begin{array}{l}\text { Completing a complex project } \\
\text { successfully motivates me }\end{array}$ & $\bigcirc$ & $\bigcirc$ & $\bigcirc$ & $\bigcirc$ & $\bigcirc$ \\
\hline $\begin{array}{l}\text { I feel that I get paid a fair amount } \\
\text { for the work I do (i.e. rates, labor } \\
\text { per hour, salary) }\end{array}$ & 0 & 0 & O & O & $\bigcirc$ \\
\hline Question & $\begin{array}{l}\text { Very } \\
\text { satisfied }\end{array}$ & $\begin{array}{l}\text { Somewhat } \\
\text { satisfied }\end{array}$ & $\begin{array}{l}\text { Neither } \\
\text { satisfied } \\
\text { nor } \\
\text { dissatisfied }\end{array}$ & $\begin{array}{l}\text { Somewhat } \\
\text { dissatisfied }\end{array}$ & $\begin{array}{l}\text { Dissatisfi } \\
\text { ed }\end{array}$ \\
\hline Requests for discounts & 0 & 0 & 0 & 0 & $\bigcirc$ \\
\hline Working in virtual teams & 0 & 0 & 0 & 0 & O \\
\hline Client review & 0 & 0 & 0 & 0 & O \\
\hline $\begin{array}{l}\text { PM matches skills of team } \\
\text { members to project requirements }\end{array}$ & O & O & O & $\bigcirc$ & $\bigcirc$ \\
\hline $\begin{array}{l}\text { Team members' flexibility with } \\
\text { schedules }\end{array}$ & $\bigcirc$ & $\bigcirc$ & 0 & 0 & $\bigcirc$ \\
\hline $\begin{array}{l}\text { Receiving answers to questions } \\
\text { about client's expectations or } \\
\text { deliverables }\end{array}$ & 0 & $\bigcirc$ & $\bigcirc$ & $\bigcirc$ & $\bigcirc$ \\
\hline $\begin{array}{l}\text { Project manager provides } \\
\text { reference materials and other } \\
\text { resources (Style guide, TM, } \\
\text { termbase, etc) necessary to } \\
\text { complete the task }\end{array}$ & 0 & 0 & 0 & $\bigcirc$ & $\bigcirc$ \\
\hline $\begin{array}{l}\text { Receiving constant feedback and } \\
\text { project updates }\end{array}$ & $\bigcirc$ & $\bigcirc$ & $\bigcirc$ & $\bigcirc$ & $\bigcirc$ \\
\hline Remuneration (e.g., rates, salary) & 0 & 0 & 0 & 0 & 0 \\
\hline Pay practices & 0 & 0 & 0 & 0 & 0 \\
\hline \multicolumn{5}{|l|}{ Question } & Answers \\
\hline \multicolumn{5}{|l|}{ Is your job stressful? } & Yes/No \\
\hline
\end{tabular}

